\title{
Upaya Meningkatkan Pengetahuan Ibu dalam Pemberian Makanan Pendamping Asi (MPASI) di Desa Rabutdaiyo Tahun 2021
}

\author{
Namira Wadjir Sangadji, Erna Veronika \\ Universitas Esa Unggul, Jakarta, Indonesia
}

\begin{abstract}
Abstrak
Latar belakang: Pemberian MPASI yang benar dapat mengoptimalkan tumbuh kembang anak, akan tetapi masih banyak orang tua yang belum memahami praktek pemberian MPASI yang benar. Hasil observasi menunjukan sebagian besar orang tua di Desa Rabutdaiyo belum mengetahui kapan waktu yang ideal untuk memberikan MPASI. Hampir sebagian besar orang tua di Desa Rabutdaiyo memberikan MPASI sebelum 6 bulan, bahkan ada yang kurang dari 3 bulan. Berdasarkan fakta di atas maka peneliti tertarik untuk memberikan penyuluhan sebagai upaya meningkatkan pemahaman ibu dalam pemberian makanan pendamping ASI (MPASI).

Metode: Eksperimen semu (quasi experiment) berdasarkan rancangan one group pre-posttest design digunakan dalam studi ini. Penelitian ini dilakukan secara langsung melalui intervensi penyuluhan tentang MPASI. Variabel dalam penelitian ini terdiri dari pengetahuan ibu tentang MPASI, usia ibu, pendidikan ibu, paritas dan status pemberian MPASI. Besar sampel dalam studi ini menggunakan total sampling 20 ibu yang memiliki baduta

Hasil: Analisis t-test menunjukkan ada perbedaan yang signifikan antara skor pengetahuan tentang MPASI sebelum dan sesudah intervensi

Kesimpulan: Kegiatan penyuluhan tentang MPASI di Desa Rabutdaiyo terbukti secara statistik dapat meningkatkan pengetahuan ibu tentang MPASI.

Kata kunci: Penyuluhan MPASI, tumbuh kembang, pengetahuan ibu

\section{Increasing Knowledge of Supplying Complementary Food for Child Development in Rabutdaiyo Village in 2021}

\begin{abstract}
Background: Giving the correct complimentary food to children can help them grow and develop more quickly, but many parents are unaware of this practice. According to the findings, the majority of parents in Rabutdaiyo Village do not know when it is appropriate to administer MPASI. The majority of parents in Rabutdaiyo Village provided supplemental feeding prior to the age of six months, and some even before the age of three months. The researchers are interested in undertaking counseling to boost mothers' knowledge of complementary feeding (MPASI). based on the findings above

Methods: A quasi-experiment with a one-group pre-posttest design was employed as the research approach. This research was conducted directly through counseling intervention about MPASI. Mother's awareness of complementary meals, mother's age, mother's education, parity, and status of complementary feeding were the variables in this study. A total of 20 mothers with children under the age of two were included in this study's sample size.

Result: There was a significant difference in complementary food knowledge scores before and after the intervention, according to the t-test analysis.

Conclusion: Counseling activities on MPASI in Rabutdaiyo Village were statistically proven to increase mothers' knowledge about MPASI.
\end{abstract}

Key Words: MPASI counseling, growth and development, mother's knowledge

Korespondensi: Namira Wadjir S.

Email: namira.wadjir@esaunggul.ac.id 


\section{PENDAHULUAN}

Air susu ibu (ASI) adalah makanan pokok yang ideal yang diberikan pada semester pertama kehidupan. ASI memiliki kandungan nutrien yang terdiri dari karbohidrat, lemak, dan protein (makronutrien) dan mineral dan vitamin (mikronutrien). ${ }^{2}$ Seiring bertambahnya usia anak, ketimpangan antara jumlah ASI dan kebutuhan gizi cenderung naik. Pemberian makanan pendamping ASI (MPASI) memainkan peran penting dalam menjembatani kesenjangan tersebut. ${ }^{1}$ MPASI merupakan makanan atau minuman dengan kandungan gizi yang adekuat yang diberikan bersamaan dengan ASI agar terpenuhi kebutuhan gizi pada bayi atau anak usia 6-24 bulan. ${ }^{2}$

Praktik MPASI yang tidak memadai berdampak buruk pada kesehatan dan pertumbuhan anak. Periode ini telah diakui sebagai 'jendela kritis' untuk mendorong pertumbuhan, kesehatan, dan perkembangan anak yang optimum. Pertumbuhan anak dapat menjadi terhambat jika mereka tidak mendapatkan MPASI berkualitas dalam takaran yang sesuai setelah usia 6 bulan bahkan jika mereka menerima ASI yang optimal. ${ }^{3}$

Memasuki era digital membuat semua informasi mudah dan cepat diperoleh serta disebarluaskan menggunakan teknologi digital termasuk informasi tentang MPASI. Begitu banyak informasi tentang MPASI yang berbeda-beda antara satu sumber dan sumber lainnya. Pembahasan tentang MPASI perlu dicermati dengan baik oleh ibu. Pengetahuan ibu memiliki pengaruh kepada pola pikir dan tingkat kepedulian untuk memberikan asupan makan yang tepat untuk anaknya. Hal ini didukung oleh penelitian yang menyatakan bahwa terdapat hubungan yang signifikan antara pengetahuan ibu dengan praktek pemberian MPASI. $^{4}$

Pemberian MPASI yang ideal dapat mengoptimalkan perkembangan anak, akan tetapi sebagian besar ibu-ibu yang belum memahami praktek pemberian MPASI yang benar. Pada praktiknya, pemberian MPASI banyak yang diberikan secara tidak optimal. Terdapat beberapa faktor yang menyebabkan ibu tidak memberikan MPASI secara adekuat yaitu ketidakhadiran pemeriksaan pasca kelahiran oleh ibu, kepercayaan dan kebiasaan budaya, kemiskinan rumah tangga dan persalinan di rumah. Selain itu faktor pendidikan dan pengetahuan juga turut berkontribusi. ${ }^{5.6}$ Penelitian lain menyebutkan bahwa promosi dan pelatihan tentang pengetahuan MPASI serta keterlibatan orang terdekat seperti ayah, ibu, kakek, dan nenek perlu dilakukan untuk mengatasi masalah tersebut. $^{7}$

Di masa kini, Indonesia masih memiliki masalah gizi yang cukup menantang seperti perkembangan bayi dibawah dua tahun (baduta). Permasalahan ini tidak boleh dianggap ringan karena masa tersebut adalah waktu krusial (golden age) dalam perkembangan kecerdasan maupun fisik anak. ${ }^{10}$ Hasil Riset Kesehatan Dasar (RISKESDAS) Kementerian Kesehatan 2018 menunjukkan $17,7 \%$ bayi usia di bawah 5 tahun (balita) masih mengalami masalah gizi. Angka tersebut terdiri atas balita yang mengalami gizi buruk sebesar 3,9\% dan yang menderita gizi kurang sebesar $13,8 \%$. Provinsi Maluku Utara menduduki peringkat ketiga untuk provinsi yang paling banyak terdapat gizi buruk pada baduta yakni mencapai 6,5\%. Peringkat pertama adalah Provinsi Maluku dan peringkat kedua adalah Provinsi NTT. ${ }^{8}$

Desa Rabutdaiyo merupakan desa yang terletak di Kecamatan Pulau Makian Kabupaten Halmahera Selatan. Bersumber dari data yang diakses dari Dinas Kesehatan Provinsi Maluku Utara, Kabupaten Halmahera Selatan merupakan Kabupaten yang paling tinggi angka gizi buruk dibandingkan dengan Kabupaten sekitar yang ada di Maluku Utara. ${ }^{9}$ Salah satu Desa yang ada di Kabupaten Halmahera Selatan adalah Desa Rabutdaiyo. Jumlah populasi Desa Rabutdaiyo adalah 730 jiwa. Di Desa ini terdapat 1 posyandu yang dimanfaatkan untuk pemberian imunisasi serta penimbangan bayi dan balita, namun diketahui belum pernah dilakukan penyuluhan mengenai MPASI. Jumlah keseluruhan baduta di Desa Rabutdaiyo mencapai 27 orang. Pada tahun 2020 ditemukan 4 baduta mengalami gizi buruk. Berdasarkan hasil diskusi dengan bidan posyandu di Desa Rabutdaiyo diketahui sebagian besar pengasuh balita di Desa Rabutdaiyo belum menyadari kapan waktu yang baik untuk memberikan MPASI. Hampir sebagian besar pengasuh balita di Desa Rabutdaiyo memberikan MPASI sebelum 6 bulan, bahkan ada yang kurang dari 3 bulan. Berdasarkan fakta di atas maka 
peneliti tertarik untuk memberika penyuluhan sebagai upaya peningkatan pemahaman ibu dalam upaya aktivitas pemberian makanan pendamping ASI (MPASI).

\section{METODE}

One group pre and post test design berbasis Eksperimen Semu (quasi experiment) adalah jenis penelitian pada studi ini. Studi ini tidak melibatkan kelompok pembanding atau kontrol sebagai perbandingan pengetahuan ibu tentang pemberian MPASI sebelum dan setelah dilakukannya penyuluhan.

Penelitian dilaksanakan pada bulan Maret tahun 2021 di posyandu Desa Rabutdaiyo, Kecamatan Pulau Makian Kabupaten Halmahera Selatan. Dua puluh ibu diambil sebagai sampel dari total populasi sebanyak 20 ibu yang memiliki bayi dua tahun (baduta) di Desa Rabutdaiyo dengan kriteria inklusi pemilihan sampel adalah ibu dengan bayi berusia 0-2 tahun yang tinggal di Desa Rabutdaiyo. Adapun atribut variabel yang perhatikan dalam studi ini mencakup karakteristik ibu yaitu usia, pendidikan terakhir, banyaknya paritas, status pemberian MPASI dan pengetahuan ibu tentang MPASI. Kuesioner yang digunakan dalam penelitian ini sebelumnya telah dilakukan uji validitas dan reliabilitas pada 10 orang ibu di Desa Walo yakni Desa yang bersebelahan dengan Desa Rabutdaiyo dengan hasil seluruh pertanyaan telah valid dan reliabel.

Penelitian ini dilakukan secara langsung dengan menerapkan aturan protokol kesehatan seperti seluruh perserta menggunakan masker medis, jarak peserta minimal 1 meter antar peserta dan menyediakan tempat cuci tangan untuk para peserta yang datang. Dalam melaksanakan penyuluhan ini, peneliti bekerjasama dengan bidan posyandu untuk menentukan waktu penyelengaraan posyandu. Kemudian peneliti dan bidan posyandu akan mempersiapkan logistik yang dibutuhkan seperti materi dalam bentuk power point dan proyektor serta kuesioner dan lembar absensi. Sebelum penyuluhan dimulai peserta diminta menjawab pertanyaan yang ada pada lembar pre test untuk menilai pengetahuan peserta mengenai MPASI. Setelah peserta menjawab pre test dan mengumpulkannya maka selanjutnya adalah penyampaian materi tentang MPASI dari peneliti. Tahap akhir dari kegiatan ini adalah pengisian post test dari para peserta untuk melihat apakah ada peningkatan pengetahuan tantang MPASI setelah mengikuti penyuluhan.
Uji paired t-test merupakan metode analisis statistik untuk uji perbandingan (komparatif) yang dipakai pada studi ini untuk mengamati perbedaan atau rerata yang bermakna antara dua kelompok setelah diberikan intervensi. Uji paired t-test digunakan dalam penelitian ini karena kedua kelompok yang dibandingkan berasal dari kelompok yang sama. Perangkat lunak untuk membantu proses analisis data dilakukan adalah software SPSS. Penelitian belum melewati uji etik sebelum pengambilan data.

\section{HASIL}

Di bawah ini adalah gambaran karakteristik ibu yang memiliki baduta di Desa Rabutdaiyo. Tabel 1 menunjukan bahwa 60\% ibu berusia antara 20-35 tahun dan mempunyai pendidikan terakhir SMA yaitu $45 \%$, sedang memberikan MPASI yaitu sebesar $80 \%$ dan memiliki paritas kurang dari sama dengan 2 anak yaitu $70 \%$.

\section{Tabel 1. Karakteristik Ibu yang Memiliki Baduta di Desa Rabutdaiyo}

\begin{tabular}{lcc}
\hline \multicolumn{1}{c}{ Variabel } & $\begin{array}{c}\text { Jumlah } \\
\text { (n) }\end{array}$ & $\begin{array}{c}\text { Persentase } \\
(\%)\end{array}$ \\
\hline Umur ibu & & \\
$\quad$ Lebih dari 35 tahun & 1 & 5,0 \\
20-35 tahun & 12 & 60,0 \\
$\quad$ Kurang dari 20 & 7 & 35,0 \\
$\quad$ tahun & & \\
Total & 20 & \\
\hline Pendidikan ibu & & \\
$\quad$ Lulus SD & 5 & 25,0 \\
$\quad$ Lulus SMP & 6 & 30,0 \\
$\quad$ Lulus SMA & 9 & 45,0 \\
Total & 20 & \\
\hline Status pemberian MPASI & \\
$\quad$ Sedang memberikan & 16 & 80,0 \\
MPASI & & \\
Belum memberikan & 4 & 20,0 \\
$\quad$ MPASI & & \\
Total & 20 & \\
\hline Jumlah paritas & & \\
$>$ 2 anak & 60,0 \\
$\quad$ 2 anak & 14 & \\
Total & 20 & \\
\hline
\end{tabular}


Data pada Tabel 2 mengidikasikan adanya peningkatan pengetahuan sebelum intervensi yaitu 2,90 ke 9,65 yang didapatkan setelah pengukuran kedua. Hal ini terlihat pada perbedaan nilai mean sebelum dan sesudah intervensi mencapai 6,75. Berdasarkan hasil uji statistik yang mendapatkan angka $P$ Value $0,0001 \quad(<0,05)$, terdapat perbedaan yang signifikan dari hasil pemahaman tentang MPASI sebelum dan sesudah diberikan intervensi. Dapat disimpulkan bahwa ada hubungan antara pengetahuan ibu tentang MPASI dengan kegiatan penyuluhan tentang MPASI.

Tabel 2. Analisis $t$ test Pengetahuan Tentang MPASI pada Ibu di Desa Rabutdaiyo

\begin{tabular}{clll}
\hline $\begin{array}{c}\text { Pengetahuan } \\
\text { tentang MPASI }\end{array}$ & Mean & $\boldsymbol{n}$ & P value \\
\hline Pre test & 2,90 & 20 & \multirow{2}{*}{0,0001} \\
Pos test & 9,65 & 20 & \\
\hline
\end{tabular}

\section{PEMBAHASAN}

Studi ini melibatkan $60 \%$ ibu dengan usia 20-35 tahun. Dalam hal proporsi partisiasi ibu, studi ini serupa dengan riset sebelumnya yaitu ibu yang mengikuti kelas edukasi mayoritas berusia antara 20-35 tahun. ${ }^{10,11}$ Usia ideal untuk kematangan biologis dan psikologis adalah 20-25 tahun untuk wanita dan 25-30 tahun untuk pria. Usia pada rentang tersebut merupakan waktu terbaik untuk menikah karena secara rata-rata sudah matang dan dapat berpikir dewasa. ${ }^{12,13}$

Pendidikan ibu dalam penelitian ini lebih banyak pada lulus SMA (45\%) sesuai dengan penelitian sebelumnya. ${ }^{10,14}$ Sebagian besar ibu di Desa Rabutdaiyo adalah tamatan SMA dapat dikarenakan di Kecamatan Pulau Makian belum terdapat sekolah tinggi maupun universitas. Akses universitas yang dapat dijangkau harus ditempuh dengan transportasi laut kurang lebih 3 jam di Kota Ternate. Hal inilah yang memungkinkan kebanyakan masyarakat Pulau Makian cenderung tidak melanjutkan ke pendidikan tinggi. Rendahnya tingkat pendidikan ibu adalah salah satu penyebab minimnya pemahaman ibu tentang MPASI. Disisi lain, ibu yang memiliki level pendidikan yang lebih baik dapat lebih mudah menerima informasi atau mudah beradaptasi dengan hal-hal baru terkait dengan pemeliharaan kesehatannya. ${ }^{15}$

Hasil penelitian ini ditemukan sebagian besar ibu yang datang ke posyandu adalah ibu yang sedang memberikan MPASI untuk anaknya yaitu sebesar $80 \%$. Sesuai dengan D.Meriyani (2020) yang menyatakan sebagian besar ibu yang ikut kelas pendampingan MPASI adalah ibu yang sedang memberikan MPASI untuk anaknya yaitu sebesar $87,6 \%{ }^{16}$

Penelitian ini juga menunjukan bahwa ibu yang memiliki paritas kurang dari sama dengan 2 anak lebih banyak yaitu 70\%. Fakta dari penelitan serupa bahwa sebagian besar ibu yang ikut kelas edukasi mempunyai paritas kurang dari sama dengan 2 anak. ${ }^{10,14} \mathrm{Hal}$ ini bertemu dengan teori yang mengatakan bahwa pengalaman dalam memberikan ASI atau MPASI kepada bayi dipengaruhi oleh jumlah persalinan yang dialami ${ }^{17}$. Diyakini terdapat hubungan antara paritas dengan arah pencarian informasi terkait pemahaman ibu nifas atau menyusui dalam membagikan ASI eksklusif dan MPASI. Hal ini terkait dengan pengalaman sendiri dan orang lain terhadap pengetahuan yang dapat berefek pada perilaku saat ini atau di masa depan. ${ }^{18}$

Mengikuti hasisl analisis t-test ditemukan adanya selisih nilai mean sebelum dan sesudah intervensi dan nilai $p$ value menunjukan ada disparitas yang signifikan antara skor pengetahuan tentang MPASI sebelum dan sesudah dilakukan intervensi. Peningkatan skor pengetahuan juga terjadi pada studi serupa bahwa terjadi peningkatan pengetahuan ibu sebelum dan sesudah diberikannya kelas edukasi tentang MPASI. ${ }^{10,19,20}$ Hal ini sejalan dengan sasaran penyuluhan kesehatan melalui pendekatan penyebaran informasi, pesan, menancapkan keteguhan keyakinan, sehingga individu dapat menyadari dan ingin terlibat aktif dan dapat melakukan imbauan yang ada kaitannya dengan kesehatan agar terjadi penambahan pengetahuan, keterampilan, dan sikap..$^{21}$

Pengetahuan dapat bermakna hasil "tahu" dari hasil pengamatan lewat indera mata dan telinga pada suatu objek tertentu. Tidak hanya itu, pengalaman pribadi atau orang lain, sumber-sumber media masa dan lingkungan dapat menjadi sumber pengetahuan. Pengetahuan atau kemampuan kognitif seseorang adalah bagian domain yang terlalu berpengaruh bagi terwujudnya perilaku 
atau aktivitas seseorang. Pemahaman juga dapat berperan sebagai stimulus terhadap dorongan sikap dan perilaku setiap hari. ${ }^{18}$ Pengetahuan dalam makna lain merupaan suatu prosedur untuk mengetahui dan melahirkan sesuatu berdasarkan hasrat ingin tahu yang berdasarkan dari kehendak yang timbul dari dirinya. ${ }^{22}$ Semakin luasnya pengetahuan ibu tentang definisi MPASI, prinsip pemberian MPASI, manfaat MPASI dan dampak jika bayi tidak diberikan MPASI yang benar maka harapanya ibu akan semakin tergerak untuk memperhatikan tumbuh kembang anaknya. ${ }^{23}$

\section{KESIMPULAN}

Kegiatan penyuluhan tentang MPASI di Desa Rabutdaiyo terbukti secara statistik dapat meningkatkan pengetahuan ibu tentang MPASI. Saran yang dapat diberikan adalah sebaiknya pemberian materi tentang MPASI rutin diberikan saat kegiatan posyandu agar semakin banyak ibu dapat memahami dan mempraktikan pemberian MPASI dengan benar.

\section{DAFTAR PUSTAKA}

1. Agostoni C, Braegger C, Decsi T, Kolacek S, Koletzko B, Michaelsen KF, et al. Breast-feeding: A commentary by the espghan Committee on Nutrition. J Pediatr Gastroenterol Nutr. 2009;49(1):112-25.

2. Dewey KG, Adu-Afarwuah S. Systematic review of the efficacy and effectiveness of complementary feeding interventions in developing countries. Matern Child Nutr. 2008;4(SUPPL.1):24-85.

3. Kabir I, Khanam M, Agho KE, Mihrshah S, Dibley MJ, Roy wapan K. Determinants of inappropriate complementary feedingpractices in infant and young children in Bangladesh:secondary data analysis of Demographic HealthSurvey 2007. Matern Child Nutr. 2012;8.

4. Andriyani R. Hubungan Pengetahuan Ibu Tentang Mp-Asi Terhadap Waktu Pemberian Mpasi Pada Bayi. J Penelit Kesehat Suara Forikes [Internet]. 2018;9(1):1-11. Available from: http://dx.doi.org/10.1016/j.neuropsycholo gia.2015.07.010\%0Ahttp://dx.doi.org/10. 1016/j.visres.2014.07.001\%0Ahttps://doi. org/10.1016/j.humov.2018.08.006\%0Aht tp://www.ncbi.nlm.nih.gov/pubmed/2458
2474\%0Ahttps://doi.org/10.1016/j.gaitpo st.2018.12.007\%0Ahttps://doi.org/

5. Alderman H, Headey DD. How Important is Parental Education for Child Nutrition? World Dev [Internet]. 2017;94:448-64. Available from: http://dx.doi.org/10.1016/j.worlddev.201 7.02 .007

6. Issaka AI, Agho KE, Burns P, Page A, Dibley MJ. Determinants of inadequate complementary feeding practices among children aged 6-23 months in Ghana. Public Health Nutr. 2015;18(4):669-78.

7. Inayati DA, Scherbaum V, Purwestri RC, Hormann E, Wirawan NN, Suryantan J, et al. Infant feeding practices among mildly wasted children: a retrospective study on Nias Island, Indonesia [Internet]. International Breastfeeding Journal. 2013. Available from: https://internationalbreastfeedingjournal. biomedcentral.com/articles/10.1186/1746 $-4358-7-3$

8. Kementerian Kesehatan RI. Laporan Hasil Riset Kesehatan Dasar (Riskesdas) Tahun 2018. Jakarta; 2018.

9. Badan Pusat Statistik Kota Ternate. Kota Ternate Dalam Angka Tahun 2020 [Internet]. Kota Ternate; 2020. Available from:

https://ternatekota.bps.go.id/publication/d ownload.html?nrbvfeve $=$ Y2NmOGU2Mj g1NzQ4MTBhY2M2YjMxNzk0\&xzmn $=$ aHR0cHM6Ly90ZXJuYXRla290YS5ic HMuZ28uaWQvcHVibGljYXRpb24vMj AyMC8wNS8yMC9jY2Y4ZTYyODU3 NDgxMGFjYzZiMzE3OTQva290YS10 ZXJuYXRILWRhbGFtLWFuZ2thLTIw MjAuaHRtbA\%253

10. Aprillia YT, Nugraha S, Mawarni ES. Efektifitas Kelas Edukasi Makanan Pendamping ASI (MPASI) Dalam Peningkatan Pengetahuan Ibu Bayi. J Bid Ilmu Kesehat. 2019; Vol. 9,No.

11. Lestiarini S, Sulistyorini Y. Perilaku Ibu pada Pemberian Makanan Pendamping ASI (MPASI) di Kelurahan Pegirian. J PROMKES. 2020;8(1):1.

12. Lartey A. Maternal and child nutrition in Sub-Saharan Africa: Challenges and interventions. Proc Nutr Soc. 2008;67(1):105-8.

13. Badan Kependudukan dan Keluarga Berencana Nasional (BKKBN). USIA PERNIKAHAN IDEAL 21-25 TAHUN 
[Internet]. 2017. Available from: https://www.bkkbn.go.id/detailpost/bkkb n-usia-pernikahan-ideal-21-25-tahun

14. Rosnah, Kristiani, Pamungkasiwi E. Faktor pada perilaku Ibu dalam pemberian MPASI anak 6-24 bulan di Puskesmas Perumnas, Kendari. J Gizi dan Diet Indones (Indonesian J Nutr Diet. 2016;1(1):51.

15. Departemen Kesehatan RI. ASI Eksklusif Untuk Ibu Bekerja. Jakarta: Dirjen Binkesmas Direktorat Gizi Masyarakat; 2004.

16. Meriyani DA, Tangkas NMKS, Sujana IWA, Ari NNR. PENINGKATAN PENGETAHUAN IBU DALAM PEMBERIAN MP-ASI SEBAGAI UPAYA PENINGKATAN TUMBUH KEMBANG BAYI DAN BALITA. J Peduli Masy. 2020;2(September):59-64.

17. Moestue H, Huttly S. Adult education and child nutrition: The role of family and community. J Epidemiol Community Health. 2008;62(2):153-9.

18. Notoatmodjo S. Pendidikan dan Perilaku Kesehatan. Rineka Cipta; 2003.

19. Dalina Gusti HB, Masrul M. PROMOSI ASI EKSLUSIF MEMAKAI METODE KONSELING DENGAN PENYULUHAN TERHADAP PENGETAHUAN DAN SIKAP PADA IBU MENYUSUI. J Artik. 2011;6, no.1(94):4-9.
20. Kumalasari D, Soyanita E. Penyuluhan Pemilihan dan Pemberian MP-ASI di Kelurahan Bawang Kecamatan Pesantren Kota Kediri 2019. Journal [Internet]. 2019;53(9):176. Available from: https://prosidingonline.iik.ac.id/index.ph $\mathrm{p} /$ senias/article/view/98

21. Sherman J, Muehlhoff E. Developing a Nutrition and Health Education Program for Primary Schools in Zambia. J Nutr Educ Behav. 2007;39(6).

22. Suhartono. Pengembangan Keterampilan Berbicara Anak Usia Dini. Jakarta: Departemen Pendidikan Nasional; 2005.

23. Seram SNV, Punchihewa PMG. Knowledge on complementary feeding among parents of children aged 4-12 months attending a base hospital in a rural district in Sri Lanka. Sri Lanka Journalof Child Heal. 2017;46(2):139-. 